\title{
Ecosystem effects of shell aggregations and cycling in coastal waters: an example of Chesapeake Bay oyster reefs
}

G G. Waldbusser

E N. Powell

Roger L. Mann

Virginia Institute of Marine Science

Follow this and additional works at: https://scholarworks.wm.edu/vimsarticles

Part of the Marine Biology Commons

\section{Recommended Citation}

Waldbusser, G G.; Powell, E N.; and Mann, Roger L., "Ecosystem effects of shell aggregations and cycling in coastal waters: an example of Chesapeake Bay oyster reefs" (2013). VIMS Articles. 1673.

https://scholarworks.wm.edu/vimsarticles/1673

This Article is brought to you for free and open access by the Virginia Institute of Marine Science at W\&M ScholarWorks. It has been accepted for inclusion in VIMS Articles by an authorized administrator of W\&M ScholarWorks. For more information, please contact scholarworks@wm.edu. 


\title{
Ecosystem effects of shell aggregations and cycling in coastal waters: an example of Chesapeake Bay oyster reefs
}

\author{
George G. Waldbusser, ${ }^{1,4}$ Eric N. Powell, ${ }^{2,5}$ and Roger ManN ${ }^{3}$ \\ ${ }^{1}$ Oregon State University, College of Earth Ocean and Atmospheric Sciences, Corvallis, Oregon 97331 USA \\ ${ }^{2}$ Haskin Shellfish Research Laboratory, Rutgers University, Port Norris, New Jersey 08349 USA \\ ${ }^{3}$ Department of Fisheries Science, Virginia Institute of Marine Science, College of William and Mary, \\ Gloucester Point, Virginia 23062 USA
}

\begin{abstract}
Disease, overharvesting, and pollution have impaired the role of bivalves on coastal ecosystems, some to the point of functional extinction. An underappreciated function of many bivalves in these systems is shell formation. The ecological significance of bivalve shell has been recognized; geochemical effects are now more clearly being understood. A positive feedback exists between shell aggregations and healthy bivalve populations in temperate estuaries, thus linking population dynamics to shell budgets and alkalinity cycling. On oyster reefs a balanced shell budget requires healthy long-lived bivalves to maximize shell input per mortality event thereby countering shell loss. Active and dense populations of filter-feeding bivalves couple production of organic-rich waste with precipitation of calcium carbonate minerals, creating conditions favorable for alkalinity regeneration. Although the dynamics of these processes are not well described, the balance between shell burial and metabolic acid production seems the key to the extent of alkalinity production vs. carbon burial as shell. We present an estimated alkalinity budget that highlights the significant role oyster reefs once played in the Chesapeake Bay inorganic-carbon cycle. Sustainable coastal and estuarine bivalve populations require a comprehensive understanding of shell budgets and feedbacks among population dynamics, agents of shell destruction, and anthropogenic impacts on coastal carbonate chemistry.
\end{abstract}

Key words: alkalinity budget; calcium carbonate cycling; Chesapeake Bay; oyster reef; shell budget.

\section{INTRODUCTION AND BACKGROUND}

\section{Importance of shell material}

The prolific shell-building, and thus calcium carbonateproducing, bivalves have long been recognized as providing important ecosystem services to coastal estuarine and marine ecosystems. Harvesting and disease have reduced their numbers significantly in many locations, and thus reduced their ecosystem services, such as water filtration, habitat creation, and food supply. Although returning the calcium carbonate shells of harvested bivalves to the benthos has long been recognized as a resource enhancement strategy (Abbe 1988), we currently lack a comprehensive understanding of shell cycling and the contribution to near-shore ecosystem functioning. In particular the ecosystem-scale role of shells in carbonate cycling, feedbacks with population dynamics, and effects on alkalinity fluxes are poorly constrained. Given the recent attention to the global decline in oyster reefs (Beck et al. 2009), impacts of ocean acidification on nearshore habitats (Feely et al. 2010, Waldbusser et al. 2011b,

Manuscript received 9 July 2012; revised 22 October 2012; accepted 1 November 2012. Corresponding Editor (ad hoc): B. Gaylord.

${ }^{4}$ E-mail: waldbuss@coas.oregonstate.edu

5 Present address: Gulf Coast Research Laboratory, Ocean Springs, Mississippi 39564 USA.
Barton et al. 2012), and economic importance of bivalve resources, a greater understanding of shell budgets (Powell et al. 2006, Mann and Powell 2007) in the context of coastal carbonate cycling is warranted.

The role of carbonate producers can be expressed in a triumvirate of themes: provision of habitat, production of harvestable resources, and buffering of respiratory acid production. The first two of these are relatively well understood and documented for oyster reefs. Provision of habitat by shell producers is clearly articulated by the taphonomic feedback hypothesis of Kidwell and Jablonski (1983) who first rigorously recognized the interaction between ecological communities and sedimentary carbonate content. In this conceptual model, increasing shell content encourages settlement of calcifying organisms and their deaths increase the rate of carbonate addition forming a positive feedback process. A reversal wherein shell loss exceeds gain can promote the antithetical negative feedback loop that continually robs the benthos of shell carbonate thereby impeding the success of carbonate producers and further reducing carbonate supply. This appears to be the case in Chesapeake Bay (Mann and Powell 2007).

\section{Structure of an oyster reef}

Although constructed from calcium carbonate, the structure of an oyster reef differs considerably from an 
analogous coral reef. Corals place tissue between the overlying seawater and the carbonate skeleton; much of the surface carbonate exposure is thereby protected as long as live corals are present. In contrast, the oyster places the calcium carbonate between the overlying water and its tissue. As a consequence, the oyster shell is exposed during life to destructive processes, and upon the animal's death the shell is added to the accumulating reef structure. Thus, oyster reefs are built by a scaffold of dead shells and contain void spaces of seawater and organic rich biodeposits (Fig. 1). Moreover, oyster reefs are found in temperate, lower salinity estuaries that are generally less thermodynamically stable for calcium carbonate minerals. Shell formation and the interaction between the organism's physiological processes and the carbonate chemistry of the surrounding seawater influences the rate of shell formation and consequently bivalve growth (Gazeau et al. 2007, Melzner et al. 2011). Formation of calcium carbonate shell affects the inorganic carbon cycle in surrounding waters because precipitation of the mineral removes alkalinity and carbon in a molar ratio of 2:1. This relationship has been used extensively to measure calcium carbonate formation in everything from calcifying organisms to entire coral reefs; however, it has been well documented that metabolic carbon may constitute $10-30 \%$ of the carbon in calcium carbonate bivalve shells (Gillikin et al. 2007). Ignoring the respiratory carbon releases from bivalves, the mass balance of shell formation requires the production of $\mathrm{CO}_{2}$ as a result of the buffering of protons ( $\mathrm{H}^{+}$ions) produced from the stripping of bicarbonate ions (or converting metabolic $\mathrm{CO}_{2}$ to carbonate ions), and a loss of alkalinity due to the incorporation of carbonate ion into solid phase. If the calcification effect is large enough relative to the water body it is occurring in, a decrease in dissolved inorganic carbon and alkalinity, and an increase in carbon dioxide should be seen.

In opposition to shell formation, oyster shell degrades over time, a process termed "taphonomy" (Powell et al. 2006), via bioerosion from boring organisms (Carver et al. 2010) and dissolution (Powell et al. 2006, Waldbusser et al. 2011a). The degradation of oyster shell in a reef occurs in a tiered environment (Fig. 1), and results in the opposite reactions from those just described above, increasing alkalinity, carbon, and $\mathrm{pH}$. For the reef to grow, the subsurface framework must increase in thickness by the accumulation of shell due to burial and preservation beneath the taphonomically active zone (TAZ; Davies et al. 1989). Below the TAZ, the anoxic conditions exclude boring organisms and are generally more geochemically favorable for calcium carbonate preservation (Cai et al. 2006, Hu et al., 2011). Estimates of oyster shell half-life derived from Delaware Bay time-series data vary between 3 and 10 years (Powell et al. 2006), and were corroborated in a laboratory study by Waldbusser et al. (2011a). These half-lives are short in comparison to other bivalve shells in non-estuarine settings, except mussels (Powell et al. 2011). This rapid rate of degradation requires significant quantities of shell added via mortality to the reef to maintain the reef structure. The normal life span of the oyster results in an optimal shell addition rate necessitating large old animals who contribute more shell carbonate mass per mortality event (Powell and Klinck 2007, Mann et al. 2009a). Unfortunately, the onset of disease has reduced life span and compromised this evolutionary optimization (Powell et al. 2012), thus compromising the shell budget.

\section{Reefs as buffering agents}

A benefit of shell degradation is the buffering of respiratory acids (carbon dioxide and others), with biologically produced calcium carbonate resulting in alkalinity production (or, more correctly, regeneration). In the variable carbonate chemistry of estuaries and coastal zones (Hoffman et al. 2011) the regeneration of alkalinity due to shell dissolution may be an important effect to provide possible refugia from corrosive conditions. The buffering effect of clam shells in metabolically active sediments has been shown to increase settlement of larval clams (Green et al. 2009, 2012); a similar effect may be true in oyster reefs. An analogy may be drawn between the calcium carbonate counter pump of the world's oceans and the cycling of oyster shells on a reef (Fig. 2). The dissolution of biogenic calcium carbonate at depth within the world's oceans (due to increased solubility) provides alkalinity buffering to the weak acids produced by respiration (Feely et al. 2004, Rost and Riebesell 2004). We propose that oyster reefs may serve a similar role in coupling respiration of organic matter and dissolution of calcium carbonate, resulting in alkalinity regeneration in nearshore environments (with obvious differences in scale and scope). The alkalinity sequestered as carbonate ions in bivalve shells comes from the surrounding waters that are advecting past due to tides and estuarine circulation, so the oyster reef carbonate pump functions by concentrating carbonate in solid form as calcium carbonate, and some portion of this will later be regenerated by dissolution into the surrounding waters as conditions favor shell breakdown. Therefore, temporal separation (presumably diurnal and seasonal) and strong concentration gradients over small spatial scales likely provide localized buffering to these highly variable estuarine environments. Secondarily, the oysters are also producing labile substrate (biodeposits) for microbial communities that will serve to provide the weak acid for dissolution and ultimately the material to bury shells in anoxic conditions. The dynamic balance between biodeposit and metabolic acid production seems an important driver for carbon burial as shell and alkalinity regeneration. However, rates and dynamics of these processes are poorly understood. 


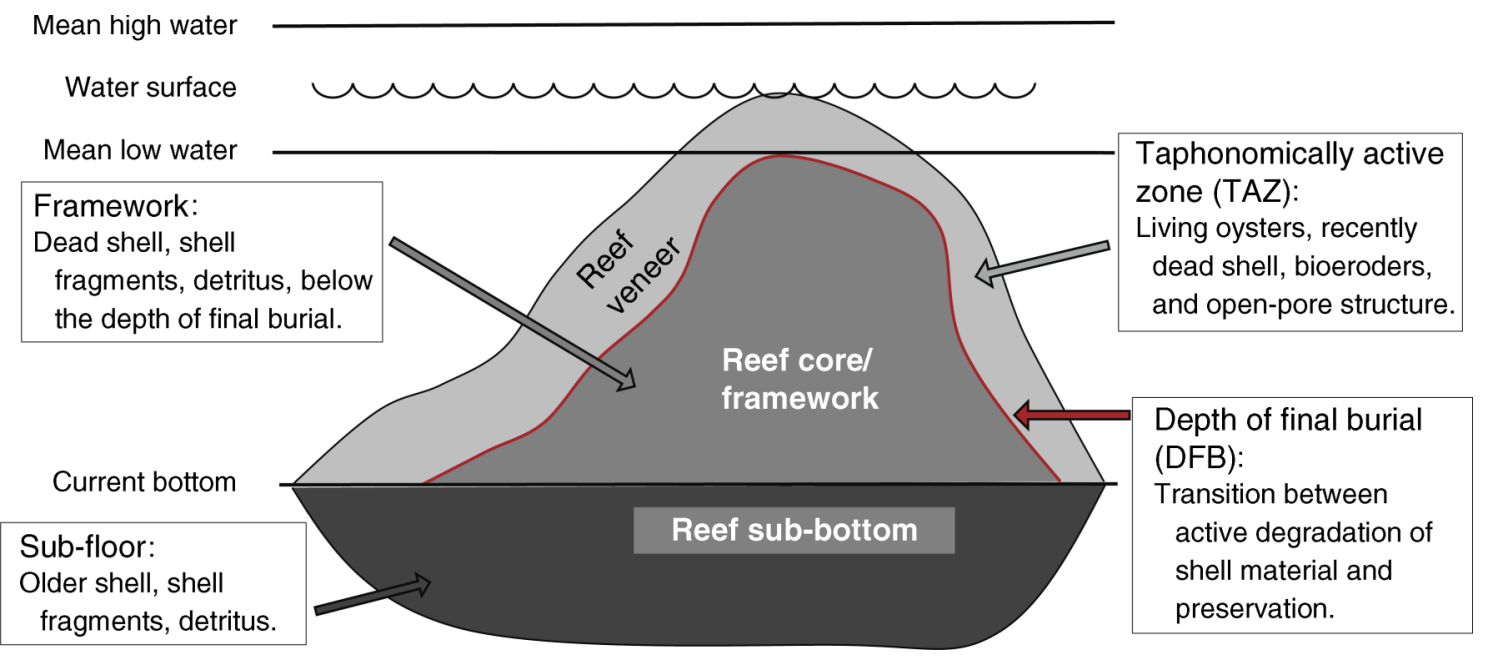

FIG. 1. Conceptual depiction of oyster reef structure, adapted from Hargis and Haven (1999). Very limited measurements of the internal physical and geochemical structure of oyster reefs have been made. Other encrusting calcifiers may also play an important role in the reef structure; however, limited understanding exists of these interactions and their effects on the geochemical and physical reef structure.

\section{Shell Budget Development}

We developed a shell budget for Chesapeake Bay in units of alkalinity to highlight the important role eastern oyster reefs once played on alkalinity and carbon cycling in this system. The results below are presented to highlight the potential role of this ecosystem service and importance in shellfish restoration efforts.

\section{Ocean exchange}

The land-ocean interactions in the coastal zone (LOICZ)-based salt and water six-box model of

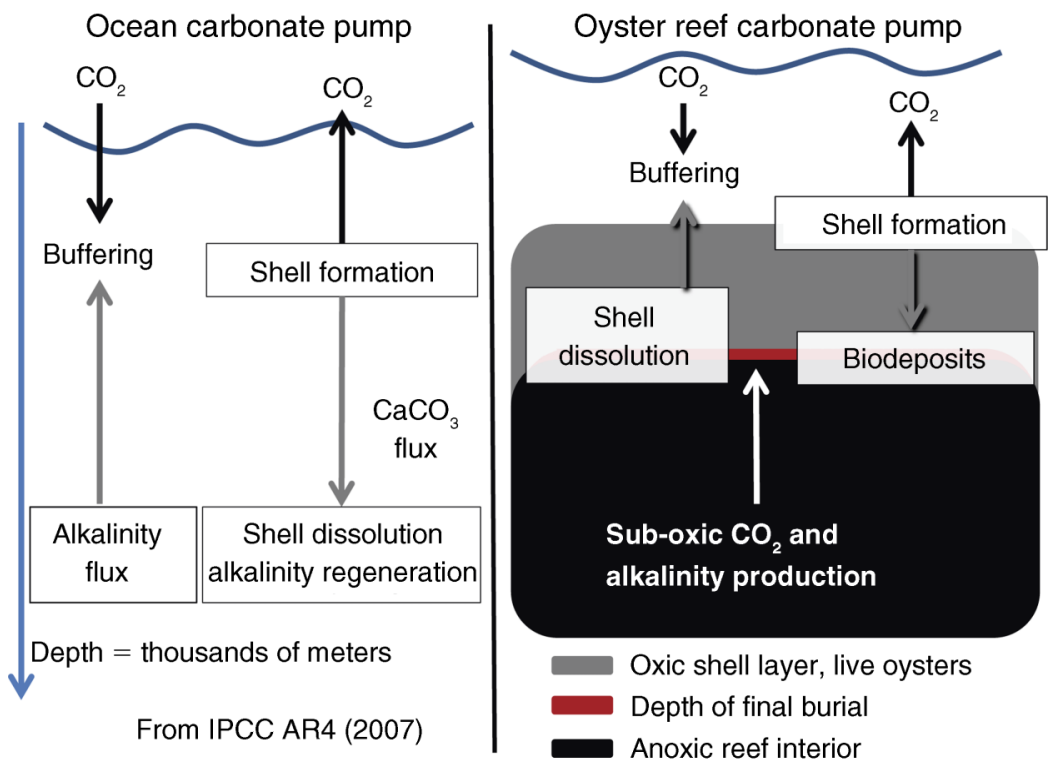

FIG. 2. Comparison between the ocean's calcium carbonate pump (redrawn from Fig. 10.7 of the 2007 Intergovernmental Panel on Climate Change, Fourth Assessment Report [AR4]) and a conceptual oyster reef carbonate pump. Formation of shell material (calcium carbonate) removes alkalinity from surrounding waters, and shell degradation regenerates alkalinity to surrounding waters. The general processes driving the pump functions are similar-production of weak metabolic acids and concurrent dissolution of calcium carbonate; however, the spatial scales and coupling of processes are different. Dissolution of calcium carbonate in the deep ocean is also driven by increased pressure. In the oyster reef carbonate-pump conceptual model, most dissolution occurs in the oxic zone; burial in the anoxic zone results in preservation, and additional alkalinity can be produced by microbial sub-oxic respiration, depending on the fate of the metabolic wastes. Production of biodeposits likely plays a key role in providing metabolic acids for alkalinity regeneration as well as, ultimately, burial and preservation of calcium carbonate shell. 
Chesapeake Bay by Webb and Smith (1999) was used to estimate ocean exchange. A nonconservative alkalinitysalinity relationship from Chesapeake Bay program data was fit with a second-order polynomial for observations with salinity values $\geq 1$ from 1986 to 2008, and applied to the salt budget (Appendix: Fig. A1, Table A1). The data set included alkalinity values from all depths which are skewed to surface waters with $\sim 66 \%$ of the $\sim 30000$ observations being from surface waters. The observations were also skewed toward the freshwater end of the bay, with the higher salinities having fewer than 25 alkalinity measurements, therefore we used the values from Wong (1979) to provide an oceanic end member with a salinity of 30 PSU (practical salinity units).

\section{Riverine input}

The river discharge values in the LOICZ model of Smith and Webb (1999) was used to compute total freshwater input into Chesapeake Bay. The average freshwater alkalinity was computed from the alkalinitysalinity relationship previously derived, and multiplied by the annual discharge of each river to obtain the total freshwater alkalinity loading. To confirm these values, the daily flow rates of the Susquehanna, Potomac, and James rivers were obtained from the USGS stream gauges and an average flow rate in liters per second was computed for each river system. This was scaled to a yearly discharge for each year and averaged for years from 1986 to 2007.

\section{Total Chesapeake Bay alkalinity}

The total volume of the mesohaline and polyhaline portions of Chesapeake Bay was obtained from the "Chesapeake Bay Program Analytical Segmentation Scheme 2004" (a technical EPA report, available online) ${ }^{6}$ by summing volumes of all mesohaline and polyhaline segments separately. The average alkalinity for each segment was determined by computing the average alkalinity across all monitoring stations within each salinity section from 1986 to 2007, and multiplying by the total volume in each section. This alkalinity estimate was compared to that derived using the LOICZ model of Webb and Smith (1999) computing the alkalinity for each box, multiplying by the box volume, and summing boxes. The two alkalinity estimates were within $10 \%$ of each other, and the LOICZ estimate is presented to maintain hydrographic consistency with the net ocean exchange estimate (the other estimate was $10.1 \times 10^{10}$ $\left.\mathrm{m}^{3}\right)$.

\section{Shell formation rate}

Shell formation was computed using two independent methods for "precolonial" time. The first was to apply a constant rate $\left(2 \mathrm{mg} \mathrm{CaCO}_{3}\right.$ per gram live mass per day; Waldbusser et al. 2011b) to the estimated total oyster

${ }^{6}$ http://www.chesapeakebay.net/content/publications/ cbp_13272.pdf biomass (described in the next section) and assuming a six-month growing period. The second was to compute the rate at which oyster reefs must grow to maintain pace with effective sea-level rise multiplied by total reef area.

The sea-level rise estimate of shell formation was carried out as follows. Mann et al. (2009a) estimated a reef accreting in equilibrium with sea-level rise at 3.5 $\mathrm{mm} / \mathrm{yr}$, and a shell loss rate of $30 \% / \mathrm{yr}$. This rate requires a production of reef volume at $4.55 \mathrm{~L} \cdot \mathrm{m}^{-2} \cdot \mathrm{yr}^{-1}$. DeAlteris (1988) estimated roughly $50 \%$ of the reef scaffold is biodeposits so the shell contribution would be half of the total, at $2.28 \mathrm{~L} \cdot \mathrm{m}^{-2} \cdot \mathrm{yr}^{-1}$. This value is supported by measurements of mass per liter of reef shell by Mann et al. (2009b). The total area of oyster reefs in Chesapeake Bay had previously been estimated at roughly $1.8 \times 10^{9} \mathrm{~m}^{2}$ by using values from Baylor (1896), Yates (1913), and Smith et al. (2001). We assume these are overestimates given that the Baylor numbers for Virginia include the coastal bays not connected to Chesapeake Bay, and these surveys tend to overestimate the spatial extent of live reefs as they assume the areas are all uniform reef. Both Yates (1913) for Maryland and Baylor (1896) for Virginia adopted mapped boundaries that included oyster habitat (reefs) and contiguous surrounding bottom as units suitable for management and regulation. To prevent overestimating the impact of reef accretion and shell degradation we used a very conservative estimate of $2.0 \times 10^{8} \mathrm{~m}^{2}$, due to the discrepancies noted above (inclusion of adjacent habitat and embayments not connected to Chesapeake Bay). The per meter estimate of shell reef volume was multiplied by our areal estimate and corrected for the approximate density of oyster shell $(1.825 \mathrm{~kg} / \mathrm{L}$, Tulshian and Wheaton 1986) to obtain a kilogram per year estimate of calcium carbonate precipitation in alkalinity equivalents. These two estimates are within twofold of each other, and below we will present the estimate based on biomass.

\section{Oyster biomass/abundance}

For the time periods of precolonial, 1880, and 1988 the dry mass estimates of oyster biomass by Newell (1988) were used in calculations as follows. Dry mass was converted to fresh tissue mass by assuming that tissue is $\sim 80 \%$ water. This value was then used to convert to total and shell masses by assuming the shell is $\sim 80 \%$ of the total mass of an oyster. The shell mass was then converted to alkalinity equivalents by the formula mass of calcium carbonate. To estimate more recent oyster abundance, the Chesapeake Bay Oyster Population Estimation (CBOPE) program data were used for oyster abundance in both the Maryland and Virginia portions of Chesapeake Bay in 2002 (data available online). ${ }^{7}$ These data were used to convert abundance to

\footnotetext{
${ }^{7}$ http://web.vims.edu/mollusc/cbope/index.htm
} 




FIG. 3. An open Chesapeake Bay shell-alkalinity budget. Units are moles or mole equivalents (shell) of alkalinity with exchanges in moles (or mole equivalents) of alkalinity per year. Stocks are in total moles (or mole equivalents) and are indicated by square brackets. Values computed for four time periods by year are shown as follows: pre-1870 in black, 1880 in blue, 1988 in green, and 2002 in red. Exchanges derived by difference are noted in the lighter blue arrows with the dashed outline. "Hydrographic exchange" is the amount of alkalinity carried out with water discharge, and "Ocean-mixing exchange" is what is transported in due to tidal mixing of higher alkalinity waters with lower alkalinity bay waters. "Net hydrographic exchange" is the difference between these two ocean-bay exchange terms, and the difference between riverine input and net hydrographic results in an estimated baywide alkalinity uptake/loss of $4.95 \times 10^{10} \mathrm{~mol} / \mathrm{yr}$.

an alkalinity equivalent for 2002 as follows. Shell mass can be predicted by the equation $\mathrm{SM}=0.00041 L^{2.70}$ where SM is shell mass and $L$ is the length along the long axis of shell growth. Assuming the average oyster at harvest is $76.4 \mathrm{~mm}$, the average shell mass would be 49.4 $\mathrm{g}$ for the 2002 CBPOE program data. Historical harvest and shell planting were estimated using a conversion of $12.9 \mathrm{~kg}$ of shell per bushel.

\section{RESUlts AND DisCusSiON}

We have estimated an alkalinity budget for Chesapeake Bay in relation to the changes in oyster abundance (Fig. 3). Some prominent features of our data compilation and calculations are (1) the potentially important role that oyster reefs may have played in the pre-harvested and early colonial Chesapeake Bay alkalinity budget; (2) roughly half of the present-day incoming alkalinity to Chesapeake Bay via riverine input could have been taken up by precolonial oyster reefs; (3) precolonial alkalinity equivalents in live shell was roughly equal to the current total dissolved alkalinity in the bay; and (4) the balance of riverine input vs. net output at the mouth of the bay indicates the bay is currently a sink of alkalinity $\left(49.5 \times 10^{9} \mathrm{~mol} / \mathrm{yr}\right)$. Similar to the loss of ecosystem function via oyster filter feeding as calculated by Newell (1988), the total amount of alkalinity sequestered by calcification decreased roughly 100-fold by 1988 due to overharvesting and disease. Our estimates indicate oyster calcification for pre-1870, 1880, 1988, and 2002 to be about $67 \%, 40 \%$, $0.7 \%$, and $4 \%$, respectively, of the currently estimated bay-wide alkalinity sink. Although we cannot reconstruct the alkalinity budget for previous periods of time this comparison highlights that oyster calcification (and subsequent shell cycling) had significant impacts on the bay-wide alkalinity budget during periods of greater oyster abundance. Conversely, the loss (or removal) of shell from the system also would result in a loss of alkalinity regeneration and buffering of metabolic acids, another seemingly important ecosystem function. If we assume shell breakdown and dissolution is roughly $10 \%$ per year (Powell and Klinck 2007, Waldbusser et al. $2011 a$ ), the estimates of alkalinity regeneration from precolonial reefs would be roughly $14 \%$ of the current riverine input (perhaps higher during the diminished alkalinity loading in the early 1900s, Raymond and Oh 2009). Note that we are basing this $10 \%$ dissolution on the live shell biomass estimates; the dead and dissolving shell within the taphonomically active zone (TAZ) would be a larger proportion of the total reef, therefore this $14 \%$ alkalinity regeneration is likely an underestimate.

The bay-wide estimate of an alkalinity loss of $49.5 \times$ $10^{9} \mathrm{~mol} / \mathrm{yr}$ based on river inputs and net ocean efflux 
would suggest a per area calcium carbonate formation rate of $225 \mathrm{~g} \mathrm{CaCO}_{3} \cdot \mathrm{m}^{-2} \cdot \mathrm{yr}^{-1}$, if the loss is entirely due to calcium carbonate formation. The removal of alkalinity is illustrated in the concave relationship between alkalinity and salinity (Appendix). The baywide alkalinity loss is not unreasonable relative to other estimates of per area calcium carbonate formation by other calcifiers in temperate estuaries (Chauvaud et al. 2003). Our bay-wide estimate is integrating all possible alkalinity sinks including all calcifiers, and other biogeochemical processes that result in alkalinity loss (reviewed in Soetaert et al. 2007). For example, primary production and aerobic respiration of organic matter can raise and lower alkalinity, respectively, due to changes in nutrient concentrations. Nutrient budgets for Chesapeake Bay (Boynton et al. 1995) suggest this effect would be to increase alkalinity due to a bay-wide nutrient sink and would be $<10 \%$ of the estimated alkalinity loss. The drivers of bay-wide alkalinity change are poorly constrained, and it is unclear whether restoring reefs to precolonial extent would result in an additive effect on alkalinity uptake, or result in a more dynamic feedback on bay-wide alkalinity.

It may seem initially odd that calcification is roughly three times greater than the shell loss term, and suggests oyster reefs as a sink of alkalinity. Healthy, intact oyster reefs are limited in vertical growth by tidal exposure, so as compaction occurs and sea level rises, reefs have more room to grow. Therefore, one may argue that on preanthropogenic reefs burial and preservation may occur as sea level rises. In the present day, most oyster reefs are not reaching their upper vertical limit (sensu Beck et al. 2009). Effective sea-level rise in Chesapeake Bay is on average twice that of the open ocean (and decreases up bay) as the watershed is subsiding at roughly the same rate as global sea-level rise. It may be surmised that on geologic timescales the rate of sea level change ultimately controls whether oyster reefs are potential alkalinity (and carbon) sinks or sources, lacking other impacts on carbonate cycling. Lateral extension is another mechanism for oyster reefs to grow if they are limited vertically, however lateral extension is often restricted by bottom topography and associated hydrodynamics (Hine et al. 1988, Powell et al. 1995). These dynamics on modern day oyster reefs are poorly understood and we lack the measurements to better understand the long-term balance of calcium carbonate accretion vs. loss.

Short-term, diurnal and seasonal, calcification and dissolution dynamics will likely drive important geochemical fluxes on timescales relevant to oyster settlement and recruitment. On annual and diurnal timescales oyster reefs may be sources or sinks of alkalinity depending on bay-wide respiration, population and disease dynamics, and ultimately the shell budget. Although we present values per annum, estuaries are highly variable (Hoffmann et al. 2011) and can serve as alkalinity producers if respiration is coupled in some way to carbonate minerals (e.g., Abril et al. 2003, Burdige et al. 2008). The precolonial oyster shell mass in Chesapeake Bay appears to have been large enough to modulate estuarine carbonate chemistry by metabolic dissolution during bay-wide or reef-wide increases in $\mathrm{CO}_{2}$ production, or other changes in carbonate chemistry resulting in more corrosive conditions. This potential buffering capacity has been diminished by over 100-fold since the former days of expansive oyster reefs within Chesapeake Bay, coupled with a shift from benthic/oyster-associated respiration to pelagic respiration not associated with shell production (Newell et al. 2005, Condon et al. 2009). Following death and disarticulation, oyster shells may dissolve more rapidly initially (Hetch 1933, Glover and Kidwell 1993, Waldbusser et al. 2011a). Therefore, our estimate of $10 \%$ shell dissolution is an integrated and conservative value, and does not account for the seasonal timing or feedbacks that occur on sub-annual timescales. Ultimately, when considering the role of harvesting and shell planting on alkalinity in estuarine ecosystems, it is important to recall that the calcification process generates $\mathrm{CO}_{2}$ and solid carbonate; thus, removing shell from the system without replacement produces acidity without concurrent production of potential buffering due to the regeneration of alkalinity during shell breakdown and dissolution.

In a retrospective reconstruction such as this, several uncertainties are evident. Applying the LOICZ (landocean interaction in the coastal zone) hydrographic approach (Smith and Webb 1999) and utilizing an empirical salinity-alkalinity relationship rely on wellconstrained values for the bay-wide alkalinity exchanges. The estimates of oyster biomass and abundance are also a relatively robust component of our budget. We, however, have applied constant rates to these biomass/ abundance estimates and caution that these rate values have likely changed over the last 150 years in response to myriad processes. We unfortunately lack data on the alkalinity of Chesapeake Bay (and river end members) during the precolonial and early colonial days. Raymond and Oh's (2009) elegant reconstruction of the Susquehanna alkalinity through the mid-1900s shows an alkalinity increase following suspension of major mining activities in the watershed. It is unknown what the Susquehanna acidification effect due to mining activities would have had on the oyster shell budget, but dissolution of shell would have presumably increased in response to the decreased alkalinity delivered to the Chesapeake Bay waters. We are treating the fresh water end member as a single value, whereas differences exist in alkalinity based on major watershed lithology. Integrating rates over an annual timescale likely results in masking important scales of variability for early lifehistory dynamics. And although the LOICZ model treats the boxes as well mixed, Chesapeake Bay is a vertically stratified system, and it may be possible that the salinity-alkalinity relationship and subsequent esti- 


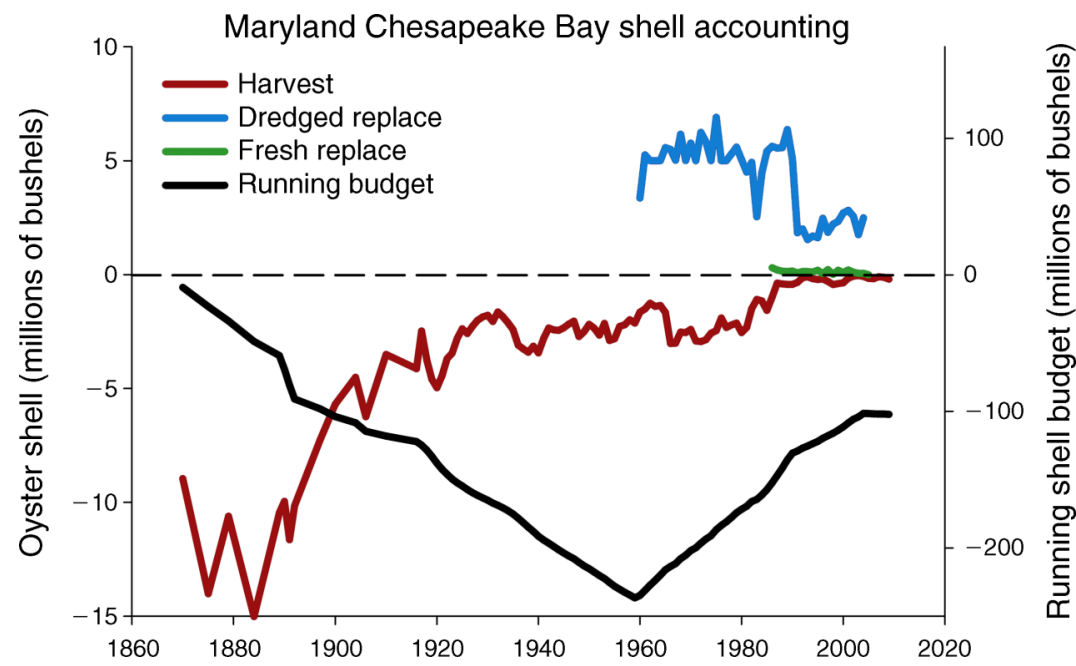

FIG. 4. A simple oyster shell accounting of harvest and replacement in the Maryland portion of Chesapeake Bay, in millions of bushels (conversion: $12.9 \mathrm{~kg}$ of shell per bushel), by year (data source: Maryland Department of Natural Resources). The "dredged replace" shells are from the Maryland dredged-shell program. The "fresh replace" shells are from the fresh-shell-planting program. The running budget, on the right $y$-axis, is the simple tally of removed vs. replaced shells, showing the positive effect of the replacement programs on the overall shell budget. It is important to note that this budget does not account for the degradation processes of shells in the bay.

mates of bay-ocean exchange we developed could be improved with a better hydrographic model. These limitations aside, our results do highlight the importance of oyster reefs on alkalinity cycling in Chesapeake Bay and the need to understand the dynamic feedbacks between alkalinity cycling and oyster shell budgets for restoration efforts.

\section{Balancing the shell budget}

Balancing the degradation and loss of shell from oyster reefs and maintaining vertical position in the water column requires large, long-lived oysters that contribute maximum shell per mortality event (Powell and Klinck 2007, Mann et al. 2009a). This is a sobering fact given that natural oyster recruitment is often infrequent (Southworth and Mann 2004, Kimmel and Newell 2007, Powell et al. 2008) and the timescales of strong year-class recruitment are very similar to shell half-lives. The similar natural timescales of shell input and loss suggest the persistence of shell might be imperiled with little additional shell loss from harvesting or disease (Powell et al. 2012). In a progressive management approach, the state of Maryland began extensive replanting of oyster shell in Chesapeake Bay in 1960. A simple accounting of harvest and shell replacement (Fig. 4) highlights the significant role of the dredge program in creating an annual surplus of shells, thus reducing the overall shell deficit. However, when the shell replacement program ended in 2005, the shell budget in the Maryland portion of the bay was still 100 million bushels below early-colonial times. This simple accounting does not take into consideration the various shell degradation processes that ultimately lead to shell breakdown in these environments, and the possibility that dredged shell was more robust to degradation than fresh shells due to the modification of the shell surface during burial (Waldbusser et al. 2011a). Shell requirements to ultimately reduce the current carbonate deficit would be equal to the harvested amount, plus degradation minus what is added through growth; these values are all poorly constrained and require significant work to quantify (Powell et al. 2012).

Our food, coastal economies, and ecosystems rely on some of the most prolific shell producers found in estuarine environments, bivalves. The shell of many commercially important bivalves may be $80-90 \%$ of the total organism mass and represents a potentially significant investment of resources on behalf of the organism. Estimates from other mollusks suggest shell formation may be equivalent to $75 \%$ of the energy invested in somatic growth (Palmer 1992). With a few notable exceptions, the shells from bivalves are often considered waste material and discarded; shells are rarely managed in a way to protect the shell resource (Gutiérrez et al. 2003, Green et al. 2009, Kelly et al. 2011). The biogeochemical role shells play in estuarine and coastal carbon cycling is virtually unexplored. New research directions are needed to understand the diminishing shell resource and its ultimate impact on the coastal ecosystems we rely upon, particularly in light of recent recognition of the acidification of estuaries from multiple drivers.

\section{ACKNOWLEDGMENTS}

The authors thank one anonymous reviewer for critical feedback and S. V. Smith for his review, conversations, and time, which improved the alkalinity budget presented here. Comments from S. E. Kolesar and I. Giménez improved 
previous versions of the manuscript. This work was supported in part by NSF OCE number 0622999 to G. G. Waldbusser.

\section{Literature Cited}

Abbe, G. R. 1988. Population structure of the American oyster, Crassostrea virginica, on an oyster bar in central Chesapeake Bay: changes associated with shell planting and increased recruitment. Journal of Shellfish Research 7:33-40.

Abril, G., H. Etcheber, B. Delille, M. Frankignoulle, and A. V. Borges. 2003. Carbonate dissolution in the turbid and eutrophic Loire estuary. Marine Ecology Progress Series 259:129-138.

Barton, A., B. Hales, G. G. Waldbusser, C. Langdon, and R. A. Feely. 2012. The Pacific Oyster, Crassostrea gigas, shows negative correlation to naturally elevated carbon dioxide levels: implications for near-term ocean acidification effects. Limnology and Oceanography 57:698-710.

Baylor, J. B. 1896. Method of defining and locating natural oyster beds, rocks and shoals. Oyster Records (pamphlets, one for each Tidewater, Virginia, county, that listed the precise boundaries of the Baylor Survey). Board of Fisheries of Virginia, Richmond, Virginia, USA.

Beck, M. W., et al. 2009. Shellfish reefs at risk. A global analysis of problems and solutions. The Nature Conservancy, Arlington, Virginia, USA.

Boynton, W. R., J. H. Garber, R. Summers, and W. M. Kemp. 1995. Inputs, transformations, and transport of nitrogen and phosphorus in Chesapeake Bay and selected tributaries. Estuaries 18:285-314.

Burdige, D. J., R. C. Zimmerman, and X. Hu. 2008. Rates of carbonate dissolution in permeable sediments estimated from pore-water profiles: the role of sea grasses. Limnology and Oceanography 53:549-565.

Cai, W.-J., F. Z. Chen, E. N. Powell, S. E. Walker, K. M. Parsons-Hubbard, , G. M. Staff, Y. C. Wang, K. A. AshtonAlcox, W. R. Callender and C. E. Brett. 2006. Preferential dissolution of carbonate shells driven by petroleum seep activity in the Gulf of Mexico. Earth and Planetary Science Letters 248:227-243.

Carver, C. E., I. Theriault, and A. L. Mallet. 2010. Infection of cultured eastern oysters Crassostrea virginica, by the boring sponge Cliona celata, with emphasis on sponge life history and mitigation strategies. Journal of Shellfish Research 29:905-915.

Chauvaud, L., J. K. Thompson, J. E. Cloern, and G. Thouzeau. 2003. Clams as $\mathrm{CO}_{2}$ generators: the Potamocorbula amurensis example in San Francisco Bay. Limnology and Oceanography 48:2086-2092.

Condon, R. H., D. K. Steinberg, and D. A. Bronk. 2009. Production of dissolved organic matter and inorganic nutrients by gelatinous zooplankton in the York River estuary, Chesapeake Bay. Journal of Plankton Research 32:153-170.

Davies, D. J. 1989. Relative rates of shell dissolution and net sediment accumulation - a commentary: Can shell beds form by the gradual accumulation of biogenic debris on the sea floor? Lethaia 22:207-212.

DeAlteris, J. T. 1988. The geomorphic development of Wreck Shoal, a subtidal oyster reef of the James River, Virginia. Estuaries 11:240-249.

Feely, R. A., S. R. Alin, J. Newton, C. L. Sabine, M. Warner, A. Devol, C. Krembs, and C. Maloy. 2010. The combined effects of ocean acidification, mixing, and respiration on $\mathrm{pH}$ and carbonate saturation in an urbanized estuary. Estuarine, Coast and Shelf Science 88:442-449.

Feely, R. A., C. L. Sabine, K. Lee, W. Berelson, J. Kleypas, V. J. Fabry, and F. J. Millero. 2004. Impact of anthropogenic $\mathrm{CO}_{2}$ on the $\mathrm{CaCO}_{3}$ system in the oceans. Science 305:362366.

Gazeau, F., C. Quiblier, J. M. Jansen, J. P. Gattuso, J. J. Middelburg, and C. H. R. Heip. 2007. Impact of elevated
$\mathrm{CO}_{2}$ on shellfish calcification. Geophysical Research Letters 34:L07603.

Gillikin, D. P., A. Lorrain, L. Meng, and F. Dehairs. 2007. A large metabolic carbon contribution to the $\delta^{13} \mathrm{C}$ record in marine aragonitic bivalve shells. Geochimica et Cosmochimica Acta 71:2936-2946.

Glover, C. P., and S. M. Kidwell. 1993. Influence of organic matrix on the postmortem destruction of molluscan shells. Journal of Geology 101:729-747.

Green, M. A., G. G. Waldbusser, L. Hubazc, E. Cathcart, and J. Hall. 2012. Carbonate mineral saturation state as the recruitment cue for settling bivalves in marine muds. Estuaries and Coasts, in press. http://dx.doi.org/10.1007/ s12237-012-9549-0

Green, M. A., G. G. Waldbusser, S. L. Reilly, K. Emerson, and S. O'Donnell. 2009. Death by dissolution: sediment saturation state as a mortality factor for juvenile bivalves. Limnology and Oceanography 54:1037-1047.

Gutiérrez, J. L., C. G. Jones, D. L. Strayer, and O. O. Iribarne. 2003. Mollusks as ecosystem engineers: the role of shell production in aquatic habitats. Oikos 101:79-90.

Hargis, W. J., Jr., and D. S. Haven. 1999. Chesapeake oyster reefs, their importance, destruction, and guidelines for restoring them. Pages 230-250 in M. W. Luckenback, R. Mann, and J. A. Wesson, editors. Oyster reef habitat restoration. A synopsis and synthesis of approaches. Virginia institute of Marine Science Press, Gloucester Point, Virginia, USA.

Hetch, F. 1933. Der Verbleib der organischer substanz der Tiere bei meerischer Einbettung. Secnckenbergiana 15:165-249.

Hine, A. C., D. F. Belknap, J. G. Hutton, E. B. Osking, and M. W. Evans. 1988. Recent geological history and modern sedimentary processes along an incipient, low-energy, epicontinental-sea coastline: northwest Florida. Journal of Sediment Petrology 58:567-579.

Hofmann, G. E., et al. 2011. High-frequency dynamics of ocean pH: a multi-ecosystem comparison. PLoS ONE 6(12):e28983. doi:10.1371/journal.pone.0028983

$\mathrm{Hu}, \mathrm{X}$., W. J. Y. Wang, and X. Guo, and S. Luo. 2011. Geochemical environments of continental shelf-upper slope sediments in the northern Gulf of Mexico. Palaeogeography, Palaeoclimatology, Palaeoecology. doi:10.1016/j.palaeo.2011. 04.010

Kelly, R. P., W. S. Fisher, R. A. Feely, G. Waldbusser, and M. R. Caldwell. 2011. Mitigating local causes of ocean acidification with existing laws. Science 332:1036-1037.

Kidwell, S. M., and D. J. Jablonski. 1983. Taphonomic feedback: Ecological consequences of shell accumulation. Pages 195-248 in M. J. S. Tevesz and P. L. McCall, editors. Biotic interactions in recent and fossil benthic communities. Plennum Press, New York, New York, USA.

Kimmel, D. G., and R. I. E. Newell. 2007. The influence of climate variation on eastern oyster (Crassostrea virginica) juvenile abundance in Chesapeake Bay. Limnology and Oceanography 52:959-965.

Mann, R., J. M. Harding, and M. Southworth. 2009a. Reconstructing pre-colonial oyster demographics in the Chesapeake Bay, USA. Estuarine, Coastal and Shelf Science 85:217-222.

Mann, R., and E. N. Powell. 2007. Why oyster restoration goals in the Chesapeake Bay are not and probably cannot be achieved. Journal of Shellfish Research 26:905-907.

Mann, R., M. Southworth, J. M. Harding, and J. A. Wesson. $2009 \mathrm{~b}$. Population studies of the native eastern oyster, Crassostrea virginica (Gmelin, 1791), in the James River, Virgina, USA. Journal of Shellfish Research 28:193-220.

Melzner, F., P. Stange, K. Trübenbach, J. Thomsen, I. Casties, U. Panknin, S. N. Gorb, and M. A. Gutowska. 2011. Food supply and seawater $p \mathrm{CO}_{2}$ impact calcification and internal shell dissolution in the blue mussel Mytilus edulis. PLoS One 6(9):e24223. doi:10.1371/journal.pone.0024223 
Newell, R. I. E. 1988. Ecological changes in Chesapeake Bay: Are they the result of overharvesting the American oyster, Crassostrea virginica? Pages 536-546 in M. Lynch and E. C. Krome, editors. Understanding the estuary: advances in Chesapeake Bay research. Chesapeake Research Consortium, Solomons, Maryland, USA.

Newell, R. I. E., T. R. Fisher, R. R. Holyoke, and J. C. Cornwell. 2005. Influence of eastern oysters on nitrogen and phosphorus regeneration in Chesapeake Bay, USA. NATO Science Series. Role of Suspension Feeders in Ecosystems 47:93-120

Palmer, A. R. 1992. Calcification in marine mollusks: How costly is it? Proceedings of the National Academy of Sciences USA 89:1379-1382.

Powell, E. N., K. A. Ashton-Alcox, and J. N. Kraeuter, S. E. Ford, and D. Bushek. 2008. Long-term trends in oyster population dynamics in Delaware Bay: regime shifts and response to disease. Journal of Shellfish Research 27:729755.

Powell, E. N., and J. M. Klinck. 2007. Is oyster shell a sustainable estuarine resource? Journal of Shellfish Research 26:181-194

Powell, E. N., J. M. Klinck, K. A. Ashton-Alcox, E. E. Hofmann, and J. Morson. 2012. The rise and fall of Crassotrea virginica oyster reefs: the role of disease and fishing in their demise and a vignette on their management. Journal of Marine Research 70:505-558.

Powell, E. N., J. N. Kraeuter, and K. A. Ashton-Alcox. 2006. How long does oyster shell last on an oyster reef? Estuarine, Coast and Shelf Science 69:531-542.

Powell, E. N., J. Song, M. S. Ellis, and E. A. Wilson-Ormond. 1995. The status and long-term trends of oyster reefs in Galveston Bay, Texas. Journal of Shellfish Research 14:439457.

Powell, E. N., G. M. Staff, and W. R. Callender, K. A. AshtonAlcox, C. E. Brett, K. M. Parsons, S. E. Walker, and A. Raymond. 2011. Taphonomic degradation of molluscan remains during thirteen years on the continental shelf and slope of the northwestern Gulf of Mexico. Paleogeography, Paleoclimatology, Paleoecology 312:209-232.

Raymond, P. A., and N. H. Oh. 2009. Long term changes of chemical weathering products in rivers heavily impacted from acid mine drainage: Insights on the impact of coal mining on regional and global carbon and sulfur budgets. Earth and Planetary Science Letters 284:50-56.

Rost, B., and U. Riebesell. 2004. Coccolithophores and the biological pump: responses to environmental changes. Pages 99-125 in H. R. Thierstein and J. R. Young, editors. Coccolithophores: from molecular processes to global impact. Springer, Berlin, Germany.

Smith, G. F., K. N. Greenhawk, D. G. Bruce, E. B. Roach, and S. J. Jordan. 2001. A digital presentation of the Maryland oyster habitat and associated bottom types in the Chesapeake Bay (1974-1983). Journal of Shellfish Research 20:197-206.

Smith, S. V., and K. L. Webb. 1999. NP budget of Chesapeake Bay, USA. Land-Ocean Interactions in the Coastal Zone Regional Modeling Node. http://nest.su.se/mnode/ North $\% 20$ America/chesapeake/ches $2 /$ ches $2 . h t m$

Soetaert, K., A. F. Hofmann, J. J. Middelburg, F. J. R. Meysman, and J. Greenwood. 2007. The effect of biogeochemical processes on $\mathrm{pH}$. Marine Chemistry 105:30-51.

Southworth, M., and R. Mann. 2004. Decadal scale changes in seasonal patterns of oyster recruitment in the Virginia sub estuaries of the Chesapeake Bay. Journal of Shellfish Research 23:391-402.

Tulshian, N., and F. Wheaton. 1986. Oyster (CrassostreaVirginica) shell thermal conductivity technique and determination. Transactions of the ASABE 29:626-632.

Waldbusser, G. G., R. Steenson, and M. A. Green. $2011 a$. Oyster shell dissolution rates in estuarine waters: Effects of acidification and shell legacy. Journal of Shellfish Research 30:659-669.

Waldbusser, G. G., E. P. Voigt, H. Bergschneider, M. A. Green, and R. I. E. Newell. 2011b. Biocalcification in the eastern oyster (Crassostrea virginica) in relation to long-term trends in Chesapeake Bay pH. Estuaries and Coasts 34:221231.

Wong, G. T. F. 1979. Alkalinity and pH in the southern Chesapeake Bay and the James River estuary. Limnology and Oceanography 24:970-977.

Yates, C. C. 1913. Summary of survey of oyster bars in Maryland, 1906-1913. U.S. Department of Commerce, Coast and Geodetic Survey, Washington, D.C., USA.

\section{Supplemental Material}

\section{Appendix}

Polynomial regression analysis and data values showing the relationship of alkalinity to salinity in Chesapeake Bay (Ecological Archives E094-076-A1). 